\title{
Innovations in the Application of Insurance-linked Securities in Non-financial Companies
}

\author{
Joanna Błach, Monika Wieczorek-Kosmala, Maria Gorczyńska \\ University of Economics in Katowice, Katowice, Poland
}

\begin{abstract}
Recently, capital market innovations within transferring insurable risk have grown in diversity. It initiated the development of innovative financial instruments, with the prime role of Insurance Linked Securities (ILS). Financial institutions (insurers in particular) remain the key players on this market. However, ILS are applicable in non-financial companies as well. Accordingly, the aim of this study is to broadly discuss the application of ILS in non-financial companies. In particular, the purpose of this paper is to provide answers to the crucial questions: (1) What are the potential areas of the use of ILS in non-financial companies? (2) What are the consequences of the use of ILS in non-financial companies? The paper is based on the application of document analysis and literature studies as its main research methods. The literature review was directed to enable the provision of systemized characteristics of ILS. Additionally, case studies were implemented to indicate the areas of ILS applications in non-financial companies. Overall, ILS in the class of financial instruments (including cat bonds, insurance derivatives, and contingent capital structures) may find potential use in non-financial companies. However, significant limitations of such a use are identifiable, mainly within the expert knowledge need and accessibility.
\end{abstract}

Keywords: risk management, financial innovations, insurance-linked securities, cat bonds, insurance derivatives

\section{Introduction}

Contemporary financial system is characterised by a high pace of innovations. Financial innovations can be defined as the process of ongoing change which results in new instruments, techniques, markets, institutions, and mechanisms that influence the situation of the financial market participants. Financial innovations are created as the response to changes in the business environment and market imperfections which have an impact on the strategy and performance of different business entities. The process of creation and implementation of financial innovations is accelerated by the globalisation of financial markets, the increased competition among financial institutions and the dynamic development of communications and information technologies.

The paper focuses on one group of financial innovations that have emerged as the result of the

\footnotetext{
* Acknowledgment: The research project was founded by National Center of Science, Poland, granted with decision No. DEC-2011/03/D/HS4/01924.

Joanna Błach, Ph.D., assistant professor, Department of Finance, Faculty of Finance and Insurance, University of Economics in Katowice, Poland.

Monika Wieczorek-Kosmala, Ph.D., assistant professor, Department of Finance, Faculty of Finance and Insurance, University of Economics in Katowice, Poland.

Maria Gorczyńska, Ph.D., assistant professor, Department of Finance, Faculty of Finance and Insurance, University of Economics in Katowice, Poland

Correspondence concerning this article should be addressed to Joanna Błach, University of Economics in Katowice, ul. 1 Maja 50, 40-287 Katowice, Poland. E-mail: jblach@ue.katowice.pl.
} 
convergence of the capital market and insurance market. These new solutions are called ILS and were created in the 1990s by insurers and reinsurers. The main purpose of ILS insurance was to improve the liquidity of the insurance market by providing the opportunity to transfer insurable risk to the capital market. However, nowadays the applications of ILS have been extended. Non-financial companies became active, applying ILS in different new ways, which are regarded here as innovative.

Recently, the transfers of insurable risk to capital markets, by the issuance of ILS, have grown in diversity. This diversity results in various forms of risk transfer innovations that can be applied in different market conditions for different purposes and lead to different results. The market for insurance-linked securities was originally developed by insurers and reinsurers, and they still remain the key players in this market. But with the development of financial markets and the spread of financial innovations, many solutions which were originally created for financial institutions have been modified and adjusted to the particular needs of non-financial entities. In this context, two important questions are to be answered: (1) What are the potential areas of the use of ILS in non-financial companies? (2) What are the consequences of the use of ILS in non-financial companies?

The paper critically analyses the innovative solutions within transferring insurable risk to the capital market. Additionally, it provides the assessment of the potential use of ILS by non-financial companies and addresses the limitations and possible consequences of these solutions. The paper relies on the document analysis as a main research method, in order to select important information and systemise characteristics of ILS as innovative solutions. It focuses exclusively on the ILS use by non-financial companies in the integrated risk management process. The analysis provided within the paper includes two groups of ILS innovations: financial instruments (catastrophe bonds, insurance derivatives, and contingent capital structures) and hybrid financial products (Industry Loss Warranties (ILW), side cars).

This is mostly a conceptual paper, based on the analysis of current literature and practical documents. However, several case studies are introduced in order to highlight the possible areas of ILS application in non-financial companies. The paper is organised as follows. In the second section, the origins of ILS in the context of the financial innovation process are briefly presented. The third section provides research results within the characteristics of the construction and mechanism of main classes of ILS. The fourth section provides findings addressing the problem of applying selected ILS in the risk management process of non-financial companies. The last section concludes the paper.

\section{Literature Review}

\section{Origins of ILS}

The financial system, with its core elements, is constantly evolving as new markets, instruments, and institutions are created and applied in order to improve its efficiency in fulfilling its fundamental functions in the economy. These new developments constitute financial innovations that have been an important part of economic history, ranging from the innovation of interest to the creation of credit default swaps (CDS) or asset backed securities (ABS). Financial innovations, in a broad meaning, are regarded as a process of on-going change, resulting in new developments in financial products, processes, and concepts, influencing the situation of all financial system participants (Błach, 2011, pp. 18-19; Gubler, 2011, p. 62; Lerner \& Tufano, 2011, p. 6). In a narrow meaning, financial innovations are associated with product innovations (innovations in financial instruments) which can be in the form of entirely new instruments, the combination or the modification of 
traditional instruments or new application of these instruments (Anderloni \& Bongini, 2009, pp. 41-43; Fabozzi $\&$ Modigliani, 2003, pp. 23-27; Frame \& White, 2009, p. 3). Consequently, financial innovations create a huge and variable group of new developments that are invented and implemented in order to increase the efficiency of the financial system in general and by this to enhance economic growth and social welfare. The process of financial innovations is enhanced by many phenomena observed in the global economy, such as, globalisation of markets, liberalisation of capital flow, dynamic changes in the business environment, increased volatility of market parameters, intensive competition between financial institutions and new developments in information and telecommunication technology (Błach, 2012, pp. 15-24).

The great variety of financial innovations result in diversified functions they can perform. Regarding the financial system perspective, the functions of financial innovations can be analysed as six main groups: (1) moving funds across time and space; (2) pooling of funds; (3) managing risk; (4) facilitating payments; (5) addressing asymmetric information problems; and (6) extracting information to support the decision-making process (Fabozzi \& Modigliani, 2003, p. 27; Llewellyn, 2009, pp. 5-7; Błach, 2011, p. 24; Lerner \& Tufano, 2011, p. 8). The analysis of all functions of financial innovations is outside the scope of this paper. Instead, this paper focuses on one function, particularly important in times of financial and economic crisis - managing risk.

There are several reasons for companies to manage risk: (1) managerial self-interest; (2) the non-linearity of taxes; (3) the existence of capital market imperfections; and (4) the cost of financial distress (Santomero, 1995, pp. 1-14). As the wealth of a manager is affected by the changes in the company's profit, they have incentive to manage risk in order to stabilise earnings, which has positive effects on their own utility. Many authors underline the importance of taxes as a rationale for risk management (Graham \& Rogers, 2002, pp. 815-839; Stulz, 1996, pp. 8-24). It is said that high volatility in pre-tax earnings leads to higher expected tax liabilities. Thus, risk management, by reducing earnings and volatility, reduces the expected tax liability and increases the expected post-tax value of the company. Another rationale for risk management is connected with capital market imperfections, in particular adverse selection problems and subsequent suboptimal investment decisions (Jensen, 1986, pp. 323-329; Froot, Scharfstein, \& Stein, 1993, pp. 1629-1658). The main role of risk management in this context is to stabilise cash flow available for investment opportunities and as a result to support the value creation process in the company. The last reason for risk management is based on the expected cost of financial distress. Risk management, by reducing the volatility of earnings, reduces the probability of a company's bankruptcy and decreases the costs of financial distress, both directly and indirectly (Mayers \& Smith, 1982, pp. 281-296). Discussed reasons are important for both the shareholders' value and managerial utility maximisation. Therefore the problem of risk management and its tools and instruments is of growing importance, in particular in times of increased business and financial risk. The process of risk management may be improved by applying financial innovations.

In the applicative sense, implementation of financial innovations in risk management is tied to methods and techniques of so-called risk treatment. Based on the adopted ISO framework, risk treatment is the end-stage of the risk management process at which an organisation decides which tools and techniques should be implemented in order to reduce the level of risk (see more about risk management process in www.lesia.insa-toulouse.fr/motet/papers/ISO_FDIS_31000_(E).pdf). In a traditional approach, risk treatment techniques cover physical risk control and financial risk control (E. J. Vaughan \& T. Vaughan, 2003, p. 17; Rejda, 2001, pp. 28-29). Physical risk control includes various techniques and methods (i.e. risk avoidance, risk prevention, or risk repression) which aim to reduce risk frequency and risk severity (Williams, Smith, \& Young, 
1998, pp. 254-255). Financial risk control includes various tools and techniques which assure a future source of financing that can be used to cover the potential loss caused by the risk occurrence. Financial risk control contains instruments of risk transfer and risk retention. Within risk transfer, an organisation shifts the responsibility to cover the consequences of risk to a third party (which is usually based on an agreement). Regarding the specifics of an organisation's activity, the main source of risk transfer is insurance risk transfer or the implementation of derivatives in their hedging functions. Retention means that an organisation provides a source of funds for covering the consequences of risk by itself (Banks, 2004, pp. 149-170; Rejda, 2001, pp. 28-29).

Over years, new developments within risk transfer and risk retention have occurred. Derivatives and structured products based on various classes of underlying assets are examples of innovations in non-insurance risk transfer instruments. Within insurance, risk transfer innovations are tied to: (1) the changes in the typical elements of insurance contract (e.g. multi-year covers, multi trigger solutions); (2) the application of parametric triggers in computing insurance indemnification; and (3) the emergence of new insurance products (e.g. business interruption insurance). Innovations in risk retention are connected to the so-called Alternative Risk Finance instruments (ARFs), characterised by a high level of customisation and the inclusion of non-insurable risks. ARFs cover, among other things, finite risk programs, MTPs (multi-line, multi-trigger products) and MMPs (multi-line, multi-year products) (Błach \& Wieczorek-Kosmala, 2013, pp. 28-31; Wieczorek-Kosmala, 2010, pp. 453-462).

Detailing the characteristics of all innovations within risk transfer and risk retention instruments is outside the scope of this paper. Instead, this paper focuses on one particular group of new risk-transfer products which allow the transferral of insurance risk to the capital market-ILS.

The emergence of ILS was facilitated by the ongoing convergence of global financial markets which appeared with the globalisation of financial services and deregulation of financial markets in Europe, USA, and Asia. It was then accelerated by the dynamic growth of derivatives and other innovative securities, advances in computer modelling and telecommunication technologies. The convergence of the financial and insurance market was, however, slower. The first and probably most powerful driver of such a convergence is the growth in property values in geographical areas prone to catastrophic risk. Unprecedented losses were caused by Hurricane Andrew in 1992 and then by Northridge Earthquake in 1994, then dwarfed by the losses in 2005 from Katrina Hurricane, Rita Hurricane and Wilma Hurricane in 2005. These catastrophes caused the hardening of the insurance market, due to the shortage of global reinsurance capacity. The prices of insurance were more than doubled, forcing the industry into efforts to find alternative sources of reinsurance capacity. Also, the promotion of holistic (or enterprise-wide risk management-ERM) influenced the convergence. The holistic approach to risk management promotes the integration of separated risk management functions, such as insurable risk, commodity risk, currency risk, interest rate risk, and etc. (Cummins \& Weiss, 2009, pp. 492-494; Frey, Kirova, \& Schmidt, 2009, p. 4).

\section{Types of ILS}

An important feature of ILS is that they represent a group of index-linked contracts, which means that payments are triggered or derived in whole or in part from the value of an independent index (trigger). There are various types of indices (triggers), depending on their construction. Four basic approaches to defining triggers are presented in Table 1. 
Table 1

Types of Triggers in ILS

\begin{tabular}{|l|l|}
\hline Trigger & Characteristic \\
\hline Indemnity trigger & $\begin{array}{l}\text { The payment occurs when actual losses on a predefined segment of the business reaches an agreed } \\
\text { level. }\end{array}$ \\
\hline Industry loss trigger & $\begin{array}{l}\text { Payment of industry claims based on a survey of industry representatives; the survey is conducted by } \\
\text { a widely recognized data provider, e.g. Property Claims Services (PCS) in USA. }\end{array}$ \\
\hline Modeled loss trigger & $\begin{array}{l}\text { Payment is determined by entering actual physical parameters into an agreed-upon, fixed model which } \\
\text { then calculates the loss. }\end{array}$ \\
\hline Pure parametric trigger & $\begin{array}{l}\text { Payment is based on the actual loss metrics characterizing physical events (e.g. earthquake magnitude, } \\
\text { wind speed). }\end{array}$ \\
\hline Parametric trigger & $\begin{array}{l}\text { A more refined version of pure parametric trigger uses more complicated formulas and more detailed } \\
\text { measures. }\end{array}$ \\
\hline
\end{tabular}
Source: Based on Frey et al. (2009, p. 6), Helfenstein and Holzheu (2006, p. 6), Banks (2004, pp. 121-122), Weber (2011, pp. 119-120), and Spry (2009, p. 12).

ILS can be divided into two groups based on the type of insurance risk: ILS based on life insurance securitisation and ILS based on non-life insurance securitisation (Weber, 2011, pp. 95-130). However, in the analysis, this paper focuses on the second approach to ILS classification based on the forms of instruments. Regarding the current state and forms of ILS as innovations, at least five broad classes need to be mentioned (see Figure. 1). There is one group of ILS covering three types of financial instruments: catastrophe bonds (cat bonds), insurance derivatives (including cat and weather derivatives), and contingent capital (CC). However, ILS innovations also include two types of hybrid financial products: ILW and side-cars. ILS in the form of financial instruments closely resemble instruments traded on capital markets. Hybrid financial products incorporate features of both financial instruments and (re)insurance (Cummins \& Weiss, 2009, pp. 506-507).

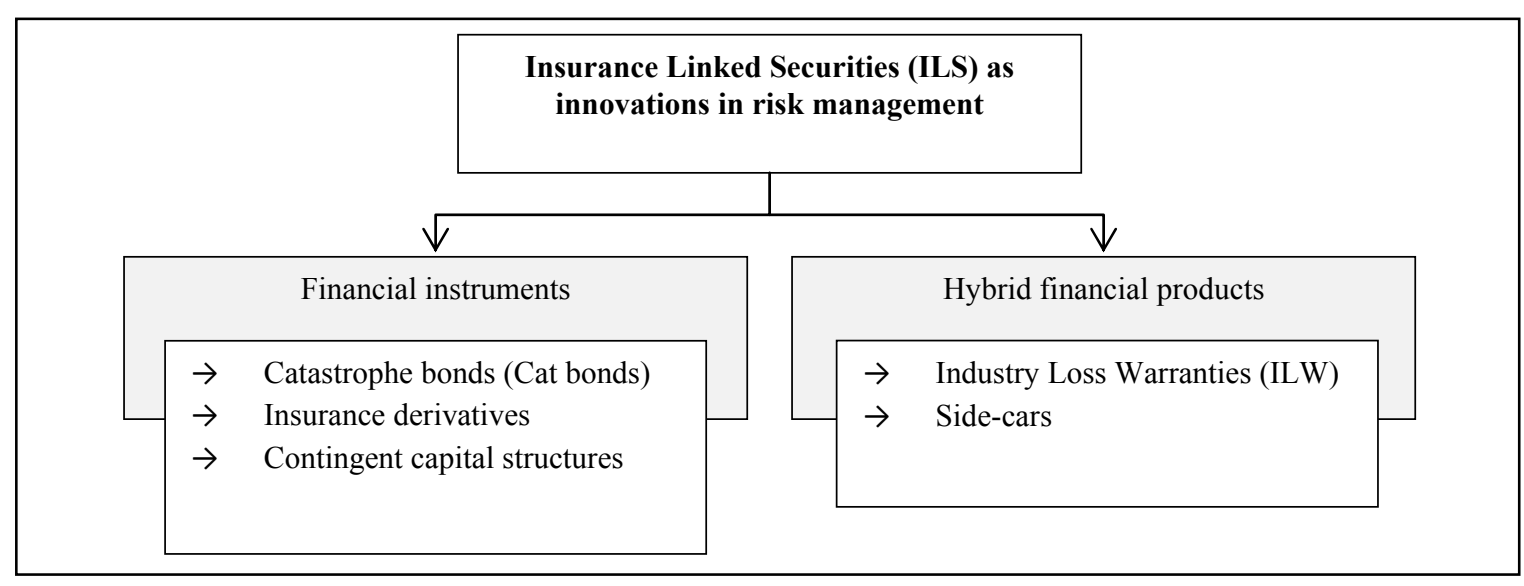

Figure 1. Classes of ILS. Source: Based on Cummins and Weiss (2009, p. 506).

Historically, the first innovation of this type was ILW which was the first index-based contracts traded and which appeared on the market in the 1980s. Then, in 1992, insurance-linked derivatives appeared in the form of cat-linked futures, listed on Chicago Board of Trade (CBOT). The first effort to transfer natural catastrophic risk to the capital market with the use of insurance-linked securities was in the mid-1990s, when Hannover reissued the first cat-linked securitisation transaction in 1994. Also, in the mid-1990s innovations with weather derivatives began and the first weather contract was traded on Chicago Mercantile Exchange (CME) (Frey et al., 2009, p. 4). Nowadays, however, cat bonds are the most successful and most recognised type of ILS 
innovations (and they have generated a much larger volume than other types of ILS) (Cummins \& Weiss, 2009, p. 521).

\section{Research Results}

\section{ILS as Financial Instruments}

The first broad class of instruments, as presented in Figure 1, includes financial instruments (catastrophe bonds), insurance derivatives, and contingent capital structures.

Catastrophe bonds (cat bonds) are fixed income securities which offer high income to investors (e.g. interest payment), but with the condition that a specified predetermined event (e.g. natural or human-inspired disaster) should occur, income payment is cancelled and the bondholder may even lose the capital invested in the bonds. If no trigger event occurs, the bondholder receives the interest and the principal at maturity. From the perspective of the issuer, cat bonds spread some risk to the buyers, who agree to accept part of this risk in return for sufficient income relative to conventional bonds (Approaches to Enterprise Risk Management, 2010, p. 197). The issuance of catastrophe bonds is based on the mechanism of securitisation. In the non-life segment of the market, so-called P\&C (Property and Casualty) market, the securitisation mechanism is used to issue bonds offering protection in mega-catastrophes, such as hurricanes and earthquakes in densely populated areas. However, the issuance of bonds in the securitisation mechanism is also implemented on the life market, to transfer so-called peak risks such as a sharp increase of mortality. Cat bonds remain the dominant form of ILS issuance on the marketplace (Banks, 2004, p. 124). There have been only very few securitisations of non-catastrophic risks, such as credit, motor, liability risks (Frey et al., 2009, p. 21). Other issuers of cat bonds than insurers are possible (Grossi \& Kunreuther, 2005; Wickham, 2008; Weber, 2011).

The second group of ILS includes insurance derivatives which are traded either on a stock exchange or over-the-counter (OTC) market. Exchange traded derivatives are usually futures and options characterised by standard contract terms, which means that all participants trade the same underlying asset. The average terms of such contracts are one to three years for non-life insurance and up to 30 years for life insurance. In insurance-linked derivatives, two groups should be distinguished, referring to the type of risk covered: catastrophe derivatives and weather derivatives (Weber, 2011, pp. 80-84).

Most catastrophe derivatives (cat derivatives) are customised, remaining traded over-the-counter. In the simplest form, a cat derivative is a binary trigger on a single event loss (as in the case of ILW). However, most of cat derivatives are catastrophe swaps which involve a series of fixed, pre-determined payments in exchange for a series of floating payments. The values of floating payments depend on the occurrence of an insured event (Frey et al., 2009, pp. 17-18; Banks, 2004, pp. 162-163). Catastrophe swaps usually cover P\&C risks, such as hurricanes, earthquakes, and terror acts. However, on the market, there are also mortality/longevity swaps which provide coverage for catastrophic life risks. In index-based transactions, a fixed series of payments is swapped for a series of payments linked to the changes in the so-called reference population. In the case of a mortality swap, the series of payments depend on the number of people who died in a given period, and in the case of a longevity (survival) swap - on the number of people who survived (Frey et al., 2009, p. 19). Catastrophe derivatives are also traded on the stock exchange. The first catastrophe derivatives were traded on CBOT in 1992 and then suspended in 2000. Recently, several exchanges have attempted to trade catastrophe derivatives. Catastrophe futures and options on hurricane risk are traded on CME and IFEX/Chicago Climate Futures Exchange (Frey et al., 2009, pp. 18-19). 
Another important group of insurance derivatives is weather derivatives, which are contracts referencing weather-related indices. Most weather derivatives are customised contracts based on temperature, precipitation (snowfall or rainfall), or wind-speed indexes. Weather derivatives provide indirect protection of profits in the case of losses caused by extreme weather conditions. Thus, active partners of weather derivatives are energy companies and recently the agribusiness and farming sectors (Frey et al., 2009, p. 20; Banks, 2004, p. 166). The market of exchange-traded weather derivatives is also expanding. Futures and options referencing temperature indexes in specific cities are listed on the CME (Banks, 2004, pp. 157-162).

The third group of financial instruments within ILS is represented by the contingent capital structure designed as a securitisation transaction similar to a put-option. A contingent capital facility allows the buyer to issue capital (common stock, hybrid capital, or debt) at a predetermined strike price in the aftermath of a loss event (a defined catastrophe event). Thus, the contingent capital structure links financial and insurance markets by offering a right to raise funds from capital market providers upon the trigger of an insurance-related event. It is designed as a multi-year product. The buyer of protection in the contingent capital structure has a right to issue additional capital after a catastrophic event and this issuance is contingent upon the occurrence of the catastrophe event, usually expressed by a given index (trigger). Thanks to such an issuance, the buyer of protection has a chance to replenish its capital (Cummins \& Weiss, 2009, p. 516; Banks, 2004, pp. 134-147; Helfenstein \& Holzheu, 2006). Contingent capital instruments are primary used by the banking sector in times of financial distress (Avdjiev, Kartasheva, \& Bogdanova, 2013). However, these instruments may be also applied by non-financials.

\section{ILS as Hybrid Financial Products}

The second broad class of ILS innovations is constituted by hybrid financial products (see Figure 1) which include ILW and side cars.

Typically, ILW are structured as indemnity (re)insurance contracts covering specified insurable losses. ILW are type of dual-trigger cover, which means that the pay-off depends on two triggers. The first trigger is called the indemnity trigger and it is the insured loss of the protection buyer. The second trigger is the insured industry loss (so-called index trigger or warranty), which can be based on either market losses or certain parameters. The contract pays off on the occurrence of a joint event, in which a specified industry-wide loss index (index trigger or warranty) exceeds a particular threshold at the same time that the issuing insurer's losses from the event equal or exceed a specified amount. An ILW contract can also be considered as a derivative when it is triggered only by an industry loss (Bouriaux \& MacMinn, 2009, p. 29). From the buyer's perspective, an ILW contract provides coverage in states of the world when its own losses are high and the (re)insurance market tends to harden. ILW are contracted on relatively low amounts (USD $1 \mathrm{~m}$ as a limit of protection), usually on a one year term. In recent years, non-insurance entities (such as hedge funds) have been the primary sellers of ILW (Cummins \& Weiss, 2009, pp. 511-512; Frey et al., 2009, p. 16; Helfenstein \& Holzheu, 2006, p. 18).

Side-cars represent a type of innovative financing vehicle, similar to conventional reinsurance, but access capital markets directly through private debt and equity investment. Side-cars are special purpose vehicles (SPVs) sponsored by reinsurers, set up to take underwriting risk from ceding (re)insurers. Side-cars help to reach additional capacity for catastrophe and marine risks, without rising expensive equity capital. Typically, side-cars have a lifetime of a few years (up to three years) and are set up in times of a hard market. There is a 
pre-defined divestment procedure to be completed before the softening of the market. Side-cars are usually owned by a holding company, which raises capital for the side-car by issuing equity and (or) debt. Side-car capital providers are private equity, hedge funds, insurers, and reinsurers. Usually, side-cars are established in Bermuda, for regulatory and tax reasons (Cummins \& Weiss, 2009, pp. 512-514; Helfenstein \& Holzheu, 2006, p. 19; Weber, 2011, pp. 87-89).

\section{Findings and Discussion}

Based on the characteristics of the main types of ILS classes, this research has selected those instruments which can be applied by the non-financial companies in the risk management process. As mentioned in second section, ILS represent risk transfer instruments used at the risk treatment stage of the risk management process. In Table 2, the features of ILS innovations with the intention to highlight which instruments are possible to be implemented in the risk management process by non-financials have been gathered. Additionally, the overview of ILS features highlights the possible areas of concern and obstacles.

Table 2

Selected Features of ILS Innovations From Risk Management Point of View

\begin{tabular}{|c|c|c|c|c|c|}
\hline Feature & Cat bonds & \begin{tabular}{|l|}
$\begin{array}{l}\text { Insurance-linked } \\
\text { derivatives }\end{array}$ \\
\end{tabular} & ILW & Contingent capital & Side-cars \\
\hline Buyers of protection & $\begin{array}{l}\text { Large primary } \\
\text { insurers reinsurers, } \\
\text { corporations and } \\
\text { government entities }\end{array}$ & $\begin{array}{l}\text { Large primary } \\
\text { insurers or } \\
\text { reinsurers, also } \\
\text { corporations }\end{array}$ & $\begin{array}{l}\text { Reinsurers, hedge } \\
\text { funds }\end{array}$ & $\begin{array}{l}\text { Primary insurers or } \\
\text { reinsurers, } \\
\text { corporations, } \\
\text { government entities }\end{array}$ & $\begin{array}{l}\text { Predominantly } \\
\text { reinsurers }\end{array}$ \\
\hline Compensation/financing & $\begin{array}{l}\text { Compensates buyer } \\
\text { against losses }\end{array}$ & $\begin{array}{l}\text { Compensates buyer } \\
\text { against losses }\end{array}$ & $\begin{array}{l}\text { Compensates buyer } \\
\text { against losses }\end{array}$ & $\begin{array}{l}\text { Provides financing } \\
\text { on pre-agreed terms } \\
\text { in case of loss event }\end{array}$ & \begin{tabular}{|l|} 
Compensates \\
reinsured against \\
losses
\end{tabular} \\
\hline Capacity providers & $\begin{array}{l}\text { Institutional } \\
\text { fixed-income } \\
\text { investors, hedge } \\
\text { funds, corporations }\end{array}$ & $\begin{array}{l}\text { Large primary } \\
\text { insurers or reinsurers }\end{array}$ & $\begin{array}{l}\text { Reinsurers, hedge } \\
\text { funds, institutional } \\
\text { investors }\end{array}$ & $\begin{array}{l}\text { Reinsurer, hedge } \\
\text { funds, commercial } \\
\text { banks, institutional } \\
\text { investors }\end{array}$ & \begin{tabular}{|l|} 
Institutional \\
fixed-income \\
investors, financial \\
sponsors (private \\
equity), hedge funds
\end{tabular} \\
\hline Intermediation & Investment banks & $\begin{array}{l}\text { Counterparties, } \\
\text { brokers }\end{array}$ & $\begin{array}{l}\text { Reinsurance } \\
\text { brokers }\end{array}$ & $\begin{array}{l}\text { Direct, reinsurance } \\
\text { brokers }\end{array}$ & $\begin{array}{l}\text { Direct, reinsurance } \\
\text { brokers }\end{array}$ \\
\hline $\begin{array}{l}\text { Complexity of } \\
\text { underwriting }\end{array}$ & $\begin{array}{l}\text { High, expected to } \\
\text { decrease as firms } \\
\text { gain experience }\end{array}$ & $\begin{array}{l}\text { High, expected to } \\
\text { decrease as firms } \\
\text { gain experience }\end{array}$ & $\begin{array}{l}\text { Low, based on } \\
\text { market risk only }\end{array}$ & High & $\begin{array}{l}\text { Varies by book of } \\
\text { insured business }\end{array}$ \\
\hline Standardization & Customized & $\begin{array}{l}\text { OTC-Customized, } \\
\text { exchange } \\
\text { traded-standardized }\end{array}$ & Customized & Customized & Customized \\
\hline
\end{tabular}

Source: Based on Helfenstein and Holzheu (2006, p. 20).

The characteristics of ILS provided in Table 2 indicate that catastrophic derivatives and side-cars represent instruments that are obtainable for reinsurers and insurers in their risk management process. The exceptions are weather derivatives that are obtainable for corporations. Non-financial companies, as the buyers of protection, may also implement cat bonds and contingent capital solutions. In addition, it should be mentioned, although it is quite rare, that all groups of ILS may be applied by non-financial companies in their investment strategy, but this problem is outside the scope of this paper.

Weather derivatives may find an important role in corporations for managing weather-related risk. There are examples of successful implementation of weather derivatives by energy supply companies. In these cases, the implementation of weather derivatives allows the reduction of financial losses in the case of fluctuations for 
the demand for energy in the time of extremely high or low temperatures. Weather derivatives are also implemented by companies operating in agriculture, transportation, construction, and tourism (Schiro \& Steinberg, 2008, p. 13; Bank \& Wiesner, 2010, pp. 581-597). The example of weather derivatives implementation in United Grain Growers (a farming company) was presented by Harrington and Niehaus (2003). Transaction costs in the case of exchange traded weather derivatives are low, but only a small number of counterparties are interested in such transactions. Therefore, the liquidity of the market is rather low. OTC contracts are more popular as they are tailor-made, but this customisation leads to higher transaction costs.

On the cat bond market, non-financial companies may perform both issuer and investor roles. Non-financial companies may decide to issue cat bonds in order to acquire protection from a pre-defined catastrophic risk, under the assumption that cat bonds offer a better solution than a traditional insurance agreement, for example, Tokyo Disneyland issued cat bonds in 1999 to protect itself against the risk of an earthquake; in 2006 FIFA issued cat bonds to insure itself against the risk of terrorism and the cancellation of the World Cup (Approaches to Enterprise Risk Management, 2010, p. 197; Banks, 2004, p. 128; Zailer, 2004, p. 108). As to investment opportunities, by purchasing cat bonds (usually with ratings below investment grade) companies receive the opportunity to earn profit relatively higher compared to traditional bonds. However, they should be aware of the risk connected with particular events that may occur before the maturity of bonds, which may cancel the interest payment and threaten the repayment of invested capital.

The implementation of a contingent capital facility is also possible for non-financial companies. This instrument is very useful for providing a relatively quick stream of cash in the case of a fortuitous event occurrence. The cash stream is obtainable for a company during the time of visible symptoms of the worsening of a company's financial situation, which is usually included in the pay-off construction of contingent capital as a second trigger. These instruments exhibit similar features to knock-in put options on equity or debt, as a company, by taking a long position in a contract, is able to exercise the option in case a specific loss has occurred (Hommel \& Gerner, 2012, p. 26). Contingent capital solutions enable a company to combine strategic risk management with financing decisions. An example of contingent capital application by Michelin (the tyre maker) is described by Culp (2002, p. 52). Contingent capital solutions are not as popular as weather derivatives, since they are regarded as quite risky instruments from the investors (capacity providers) point of view, as the trigger event specified in the contract may also affect the financial condition of the investor due to its high severity (Weber, 2011, p. 91).

However, the ILS features presented in Table 2 indicate the possible areas of concern, hardening their successful implementation by non-financial companies. First of all, the supply side of ILS market constraints should be mentioned. Standardised contracts, in the case of exchange traded instruments, may not be adequate for the company's needs and requirements. While, ILS traded on the over-the-counter market, are characterised by low liquidity. Therefore, non-financial companies may find it difficult to arrange the desired ILS. As ILS remain customised contracts, it may take some effort and time to find an intermediary willing to prepare such an agreement and an appropriate counterparty, interested in providing coverage. Thus, a company willing to implement ILS in a risk management program should carefully judge the potential transaction cost.

The second area of concern is the complexity of these instruments, which influence the demand side of the ILS market. In many cases the complexity of underwriting is high and requires deep knowledge and experience both in the capital market and risk management. This is another source of potential increase of participation 
cost, regarded as the key aspect in understanding the usage of risk management instruments (Allen \& Santomero, 1997, pp. 1461-1485). Bank and Wiesner (2010, pp. 591-594) distinguished main factors belonging to the category of participation costs: (1) lack of institutional framework - as some of companies, mostly small and medium sized ones, do not have a dedicated risk management department and professional risk managers; (2) limited expertise and lack of skills regarding the implementation of risk management instruments and tools; (3) lack of awareness of potential risk factors and risk treatment techniques; (4) negative image of insurance-linked securities, mostly derivatives presented in the context of gambling or betting; (5) regulatory issues regarding tax, accounting and legal treatment of particular ILS which can be perceived as challenging for some companies, smaller ones in particular. The extended analysis of factors determining the development of ILS securities is presented in Bouriaux and MacMinn (2009, pp. 1-34) and Bouriaux and Tomas (2014, pp. 32-58).

Both transaction and participation costs influence the efficiency of ILS application in the risk management process. Therefore, the application of these solutions should be preceded by a detailed cost-benefit analysis carried out on a case-by-case basis in order to explore whether conventional (traditional) insurance products and services would better meet the company's requirements and needs.

It seems that the implementation of ILS by non-financial companies is also limited by a company's size. Due to the specifics of these transitions (customisation) and their complexity, these solutions are rather suited to large companies with a dedicated risk management department run by professional risk managers.

\section{Conclusions}

Critical analysis of the available documents and literature review provides strong justification for the thesis that in recent years, capital market innovations within transferring insurable risk to capital markets (ILS) have grown in diversity. Obviously, these innovations are designed primarily for use by insurers. However, they may find a potential use in non-financial companies. This paper has identified those innovations which are available for non-financial companies. In particular, such innovations may be applied in order to improve the integrated risk management process. Non-financial companies may use these innovations in two ways: (1) as an alternative (substitute) to traditional risk management instruments (e.g. insurance policy), conditional upon their efficiency (to design similar coverage but at lower costs or to assure better coverage at comparable costs); (2) as complementary solutions to traditional instruments (to ensure access to tools and mechanisms not available directly through the application of traditional solutions).

However, there are relevant constraints that may limit the application of ILS by non-financials. These obstacles can be identified both on the supply and demand side of the ILS market (e.g. expensive customisation process, complex construction of instruments, requirement of professional expertise, lack of clear tax and law regulations). These limitations of the ILS market lead to an increase in transaction and participation costs, which may decrease the efficiency or risk management process.

This paper contributes to the debate on the possible use of ILS in the non-financial sector, as it focuses on the potential advantages and disadvantages of their use. An interesting field for further research on this topic is the analysis of the solutions that may diminish the impact of currently observed limitations of the use of ILS by non-financials. Accordingly, the problem of enhancing implementation of ILS by non-financials is also a promising field of study. 


\section{References}

Advjiev, S., Kartasheva, A., \& Bogdanova, B. (2013). Cocos: A primer. BIS Quarterly Review. Retrieved June 14, 2014 from http://papers.ssrn.com/sol3/papers.cfm?abstract_id=2326334

Allen, F., \& Santomero, A. M. (1997). The theory of financial intermediation. Journal of Banking and Finance, 21(1-2), 1461-1485.

Anderloni, L., \& Bongini, P. (2009). Is financial innovation still a relevant issue? In L. Anderloni, D. T. Llewellyn, \& R. H. Schmidt (Eds.), Financial innovation in retail and corporate banking (pp. 41-62). Cheltenham: Edward Elgar.

Approaches to Enterprise Risk Management (2010). London: Bloomsbury.

Bank, M., \& Wiesner, R. (2010). The use of weather derivatives by small-and medium-sized enterprises: Reasons and obstacles. Journal of Small Business and Entrepreneurship, 23(4), 581-600.

Banks, E. (2004). Alternative risk transfer: Integrated risk management through insurance, reinsurance and capital markets. Chichester: John Wiley \& Sons.

Błach, J. (2011). Financial innovations and their role in the modern financial system-Identification and systematization of the problem. Financial Internet Quarterly "E-Finanse”, 7(3), 13-26.

Błach, J. (2012). Changes in the business environment as the major motives for implementing financial innovations in the corporate financial strategy. In H. Zadora, \& G. Łukasik (Eds.), Finanse w niestabilnym otoczeniu—dylematy $i$ wyzwania. Finanse przedsiębiorstw (pp. 15-24). Katowice: Uniwersytet Ekonomiczny w Katowicach.

Błach, J., \& Wieczorek-Kosmala, M. (2013). Financial innovations in risk management-Enterprise perspective. Retrieved June 30, 2014 from http://www.ekf.vsb.cz/export/sites/ekf/frpfi/.content/galerie-dokumentu/ final-1.pdf

Bouriaux, S., \& MacMinn, R. (2009). Securitization of catastrophe risk: New developments in insurance-linked securities and derivatives. Journal of Insurance Issues, 32(1), 1-34.

Bouriaux, S., \& Tomas, M. J. (2014). Why do insurance-linked exchange traded derivatives fail. Journal of Insurance Issues, $37(1), 32-58$.

Culp, C. L. (2002). Contingent capital: Integrating corporate financing and risk management decisions. Journal of Applied Corporate Finance, 15(1), 46-56.

Cummins, J. D., \& Weiss, M. A. (2009). Convergence of insurance and financial markets: Hybrid and securitized risk-transfer solutions. The Journal of Risk and Insurance, 76(3), 493-545.

Fabozzi, F. J., \& Modigliani, F. (2003). Capital markets: Institutions and instruments. Upper Saddle River: Pearson Education International.

Frame, W. S., \& White, L. J. (2009). Technological change, financial innovation, and diffusion in banking (Working Paper, Federal Reserve Bank of Atlanta, Atlanta). Retrieved from_www.frbatlanta.org/filelegacydocs/wp0910.pdf

Frey, A., Kirova, M., \& Schmidt, C. (2009). The role of indices in transferring risks to the capital markets. Zurich: Swiss Re.

Froot, K. A., Scharfstein, D. S., \& Stein, J. C. (1993). Risk management: Coordinating corporate investment and financing policies. Journal of Finance, 48(5), 1629-1658.

Graham, J. R., \& Rogers, D. A. (2002). Do firms hedge in response to tax incentives? Journal of Finance, 57(2), 815-839.

Grossi, P., \& Kunreuther, H. (2005). Catastrophe modeling: A new approach to managing risk. New York: Springer.

Gubler, Z. J. (2011). The financial innovation process: Theory and application. Delaware Journal of Corporate Law, 36(1), 55-120.

Harrington, S., \& Niehaus, G. (2003). United grain growers: Enterprise risk management and weather risk. Risk Management and Insurance Review, 6(2), 193-208.

Helfenstein, P., \& Holzheu, T. (2006). Securitisation-New opportunities for insurers and investors. Zurich: Swiss Re.

Hommel, U., \& Gerner, M. (2012). Linking strategy to finance and risk-based capital budgeting. In U. Hommel, M. Fabich, E. Schnellenberg, \& L. Firnkorn (Eds.), The strategic CFO, creating value in a dynamic market environment (pp. 9-30). Heidelberg, Berlin: Springer.

ISO. (2009). Risk management — Principles and guidelines. ISO 31000:2009. International Standard (International Organization for Standardization). Retrieved March 3, 2011 from www.lesia.insa-toulouse.fr/motet/papers/ISO_FDIS_31000_(E).pdf

Jensen, M. C. (1986). Agency costs of free cash flow, corporate finance and takeovers. American Economic Review, 76(2), 323-329.

Lerner, J., \& Tufano, P. (2011). The consequences of financial innovation: A counterfactual research agenda (National Bureau of Economic Research Working Paper Series, Cambridge). Retrieved from http://www.nber.org/papers/w16780 
Llewellyn, D. T. (2009). Financial innovation and the economics of banking and the financial system. In, L. Anderloni, D. T. Llewellyn, \& R. Schmidt (Eds.), Financial innovation in retail and corporate banking (pp. 1-40). Cheltenham: Edward Elgar.

Mayers, D., \& Smith, C. W. (1982). On the corporate demand for insurance. Journal of Business, 55(2), 281-296.

Rejda, G. E. (2001). Principles of risk management and insurance. Boston: Addison Wesley Longman.

Santomero, A. M. (1995). Financial risk management: The whys and hows. Financial Markets, Institutions and Investments, 5(4), $1-14$.

Schiro, J. J., \& Steinberg, K. (2008). Convergence of insurance and capital markets (Working Paper). New York: World Economic Forum.

Spry, J. (2009). Non-life insurance securitization: Market overview, background and evolution. In P. Barrieu, \& L. Albertini (Eds.), The handbook of insurance-linked securities (pp. 9-19). Chichester: John Wiley \& Sons.

Stulz, R. M.. (1996). Rethinking risk management. Journal of Applied Corporate Finance, 9(3), 8-25.

Vaughan, E. J., \& Vaughan, T. (2003). Fundamentals of risk and insurance. New York: John Wiley \& Sons.

Weber, C. (2011). Insurance linked securities. The role of the banks. Wiesbaden: Gabler Verlag.

Wickham, C. H. (2008). New catastrophe bonds on hold pending reinsurance market hardening. Retrieved from $\mathrm{http}: / / \mathrm{www}$. insurancejournal.com/news/national/2008/11/24/95752.htm

Wieczorek-Kosmala, M. (2010). Innovative design of insurance risk transfer-A corporate perspective. Retrieved 30 June, 2014 from http://www.ekf.vsb.cz/export/sites/ekf/frpfi/.content/galerie-dokumentu/final-1.pdf

Williams, C. A., Smith, M. L., \& Young. P. C. (1998). Risk management and insurance. Boston: McGraw Hill.

Zailer, I. (2004). Derivatives structures as an alternative to traditional forms of insurance. Derivative Use, Trading \& Regulation, 10(2), 107-113. 